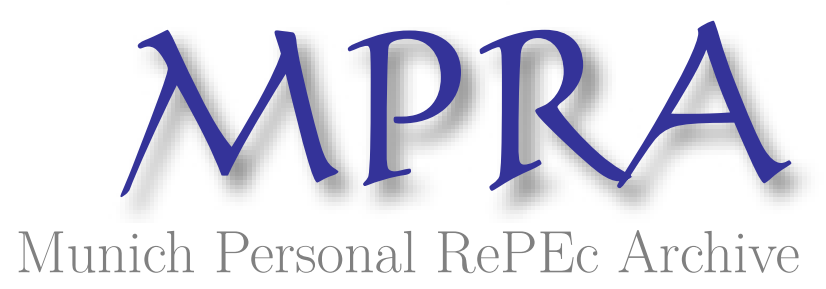

\title{
The effects of green growth, environmental-related tax, and eco-innovation towards carbon neutrality target in the US economy
}

Chien, Fengsheng and Ananzeh, Mohammed and Mirza, Farhan and Bakar, Abou and Vu, Hieu Minh and Ngo, Thanh Quang

24 August 2021

Online at https://mpra.ub.uni-muenchen.de/109664/ MPRA Paper No. 109664, posted 12 Sep 2021 03:49 UTC 


\title{
The effects of green growth, environmental-related tax, and eco-innovation towards carbon neutrality target in the US economy
}

\author{
Fengsheng Chien $^{\mathrm{a}, \mathrm{b}}$, Mohammed Ananzeh ${ }^{\mathrm{c}}$, Farhan Mirza ${ }^{\mathrm{d}}$, Abou Bakar ${ }^{\mathrm{e}}$, Hieu Minh Vu ${ }^{\mathrm{f}, *}$, \\ Thanh Quang Ngo ${ }^{g}$
}

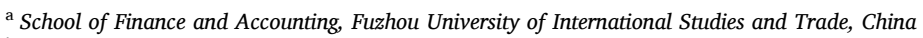

${ }^{\mathrm{b}}$ Faculty of Business, City University of Macau, Macau, China

${ }^{\mathrm{c}}$ Head of Management Department, Emirates College of Technology, United Arab Emirates

${ }^{\mathrm{d}}$ KUBEAC department, University of management and technology, Sialkot campus, Pakistan

${ }^{\mathrm{e}}$ Institute of Business Management and Administrative Sciences, The Islamia University of Bahawalpur, Pakistan

${ }^{\mathrm{f}}$ Faculty of Business Administration, Van Lang University, Vietnam 45 Nguyen Khac Nhu, 24 Dist.1, Ho Chi Minh City, Viet Nam

${ }^{\mathrm{g}}$ School of Government, University of Economics Ho Chi Minh City, Ho Chi Minh City, Viet Nam

\section{A R T I C L E I N F O}

\section{Keywords:}

$\mathrm{CO}_{2}$ emission

Ecological innovation

Environmental pollution

Green growth

USA

\begin{abstract}
A B S T R A C T
This study aims to examine the nexus between green growth and carbon neutrality targets in the context of the USA while observing the role of ecological innovation, environmental taxes, and green energy. For this purpose, data were collected from 1970 to 2015 for all the variables of interest. This research utilized the quantile autoregressive distributed lag (QARDL) method due to its various benefits, such as depicting the causality patterns based on different quantiles for different variables like green growth, ecological innovation, environmental taxes, and renewable energy. The findings through the QARDL method showed that the error correction coefficient was significant and negative with the expected negative sign for the different quantiles. The findings showed a significant and negative impact of green growth, square of green growth, ecological innovation, and environmental taxes in determining the carbon dioxide $\left(\mathrm{CO}_{2}\right)$ emissions for the USA's economy under the longrun estimation. Meanwhile, the outcome for the short-term estimation confirmed that the past and lagged values of $\mathrm{CO}_{2}$ emission were significantly and negatively linked with the current and lagged values of $\mathrm{CO}_{2}$ emission. On the other hand, it was found that green growth and square of green growth, ecological innovation, environmental taxes, and renewable energy played their vital role in reducing haze pollution like PM2.5. Besides, this research also covers the limitations and policy implications.
\end{abstract}

\section{Introduction}

With the increasing population globally, there is a growing demand for electricity and energy from different sources. However, the conventional methods to generate electricity are found to be not good in terms of carbon neutrality practices (Ji et al., 2021; Umar et al., 2021b). This is because an extensive amount of natural resources has been used to produce electricity, and this has caused a direct harmful effect on the natural environment in the form of changing climate (Su et al., 2021a; 2021b). To overcome this issue, advancements in sustainable and ecological innovations have provided some meaningful contributions while lowering the utilization of natural resources like coal and oil for energy demand (Chien et al., 2021a; Umar et al., 2021a). The outcome of such technological advancement is reflected in the form of lowering climate change instead of increasing pollution because of the burning of natural fuel products, leading to carbon dioxide $\left(\mathrm{CO}_{2}\right)$ emissions. Meanwhile, a higher level of $\mathrm{CO}_{2}$ emissions in the natural environment puts an adverse impact on green growth and causing difficulties for living things. It is believed that $\mathrm{CO}_{2}$ emission is at the top of the list among all the pollutants released by the industries in the world (Su et al., 2021; Umar et al., 2020b).

The green growth advancement has been observed in the USA's economy, where the development of solar panels started. Due to the high growth of the economy, there are high chances of environmental issues

\footnotetext{
* Corresponding author.

E-mail addresses: jianfengsheng@fzfu.edu.cn, jiafengsheng@fzfu.edu.cn (F. Chien), mohammed.ananzeh@ect.ac.ae (M. Ananzeh), mirzafarhan617@gmail.com (F. Mirza), aboubakar02@hotmail.com (A. Bakar), hieu.vm@vlu.edu.vn (H.M. Vu), thanhnq@ueh.edu.vn (T.Q. Ngo).
} 
in the USA. Thus, green growth is necessary for the USA to improve its environmental condition. In addition, the environmental-related measures in the USA are also at high to improve the environmental situation in the country, but the USA government should undertake more efforts to handle the $\mathrm{CO}_{2}$ emission in the country. Nevertheless, various other economies have also contributed to lowering the natural environment's increasing pollution. However, significant disapproval of solar panel technologies has been observed from the oil-producing countries because it will reduce the dependency on non-renewable energy sources (Hao et al., 2021; Wang et al, 2021a, 2021b). Despite the increasing rates of disapproval, the development of solar power plants in numbers is increasing dramatically. It provides the countries with the core abilities to reduce $\mathrm{CO}_{2}$ emissions (Sharif et al., 2020; Shair et al., 2021a; Wang et al., 2021c).

In addition, economic policies adopted by the government have affected the utilization of non-renewable energy sources, and such act is highly criticized by the current organizations which are working on the improvement of environmental degradation (Chien et al., 2021b; Umar et al., 2020a; Tao et al., 2021). Meanwhile, various organizations and governments highly appreciate green growth because of its major contribution towards environmental sustainability (Sharif et al., 2020; Shair et al., 2021b). Additionally, another factor contributing to lowering CO2 emissions is the environmental taxes imposed by different governments on products related to energy and observed as highly influential for increasing or decreasing $\mathrm{CO}_{2}$ emissions (Schmidt and Huenteler, 2016). From the last decade, taxes imposed by the government on solar power plants have been reduced with the core effort to enhance environmental sustainability (He et al., 2021; Li et al., 2021a; Nawaz et al., 2021a). Similarly, ecological innovation is also observed to affect the traditional economic model used by different industries while creating more environmental threats (Huang et al., 2020). In addition, while exploring the nexus between economic growth, environmental pollution, ecological innovation, and environmental taxes from the context of the USA, the estimation for both short-run and long-run are quite evident. In this regard, the quantile autoregressive distributed lag or QARDL approach suggested by (Chou and Yeh, 2015) has been applied in the present study. Additionally, it also helps to examine the locational asymmetry association between the study variables and the conditional distribution as expressed by (Suki et al., 2020; Triki-Lahiani et al., 2018). Furthermore, another reason to apply QARDL is that it helps to consider the co-integrating coefficients to change over the innovation quantile originated from shocks as expressed by (Godil et al., 2020; Shahbaz et al., 2018; Wang et al., 2021).

Environmental issues are becoming a global problem, and this has captured the attention of recent studies. This importance motivates the researchers to examine green growth, environmental-related tax, and eco-innovation impacts on carbon neutrality. In addition, a study by (Anh Tu et al., 2021) suggested that environmental issues, green finance, and growth are emerging topics and need to be examined further. Therefore, the present study will fill this gap and investigate the nexus between green growth and $\mathrm{CO}_{2}$ emissions. Moreover, a study conducted by (Chien et al., 2021a) recommended that renewable energy is the foremost solution to $\mathrm{CO}_{2}$ emission and needs to be explored. To answer this gap, the present study investigates the green growth impact on $\mathrm{CO}_{2}$ emissions. Thus, the current study examines the green growth, environmental-related tax, and eco-innovation impact on carbon neutrality. This study not only contributes to the knowledge of current literature related to $\mathrm{CO}_{2}$ emissions, environmental issues, and green growth, but also contributes to the literature of environmental-related tax and eco-innovation role on the environmental issues in the context of USA.

This chapter provides the introduction of the topic and the research gaps, contribution, and motivation of the study. The following section offers a review of previous research related to the understudy variables. The third section provides the detailed research methods used to conduct the analysis. The fourth section deals with the analysis of the results, while the final section deals with the conclusion and implications of the study.

\section{Literature review}

Due to the increasing world population, there is a considerable increase in the electricity demand, and it has significantly increased the importance of renewable energy sources. Solar power is considered the most sustainable and unlimited energy source because it has a low cost per kilowatt-hour and can be effectively used in the long term ( $\mathrm{Li}$ et al, 2005, 2021a, 2021b, 2021c; Nguyen et al., 2021). In the USA, solar power is considerably rising in demand because of the increasing potential of renewable energy sources and significant government investment (Sun et al., 2020). Most solar power generation plants are based on the utility-scale model, but it is expected to increase as the cost of production will substantially reduce in the future (Hao et al., 2021). This was evident from several studies that from the year 2015, the USA has invested considerably in solar power, which has provided jobs to more than 0.25 million people. This was possible because multiple companies were focused on improving the supply chain to fulfill the increasing demand for solar panels. It was estimated in a study that in 2019, the total power generation capacity of the solar panels installed in the USA was more than $71 \mathrm{GW}$ (Li et al., 2019). The research and development in solar panel technology started in the USA more than 30 years ago, and the availability of resources in large amounts has made it possible to achieve higher standards in solar power generation technology. Based on the neoclassical model, the USA's utility maximization approach was used to increase the scale of production of solar panels (Brookes, 2019; Malla and Brewin, 2020; Sadiq et al., 2020). This effectively reduces ecological damage and improves environmental sustainability as the country itself is going through climate change. It is predicted that by 2045 the Hawaiian Islands will be entirely dependent on renewable energy sources such as solar panels funded by the USA government. (Bibi et al., 2021; Chien et al., 2021c; Ehsanullah et al., 2021).

Most of the USA's coastal areas are equipped with solar panel facilities because these areas have more business opportunities and provide a suitable location for the utility-scale solar facility. Environmental degradation has expected to be significantly reduced by implementing a utility-scale solar panel facility (Chien et al., 2021a; Hsu et al., 2021). However, according to recent studies, the net power generation capacity of solar panels installed in the USA is still around $1.65 \%$ of the total USA electricity demand. This shows a massive gap between the supply and demand of renewable energy through solar panels in the USA. In terms of the neoclassical theory, it is expected that the government will not interfere in the solar panel market as it hampers their independence and does not fulfill market demand requirements. Conversely, in the USA, the entire solar panel market is controlled according to state officials' economic policies (Milonakis, 2012).

From an economic perspective, the balance between the supply and demand of a product is critical. Conventionally, multiple theories predict the products' price to precisely fulfill the customers' demand and provide sustainable profitability to businesses (Diesing and Diesing, 2019). The neoclassical theory is based on the economic model in which the supply and demand are already known, and it is assumed that humans have rational behavior. A business's traditional role is to maximize the profit while an individual looks to maximize the utility. Modern economics highly criticize the theory because of the assumptions that are not sustainable from realistic scenarios whereby these assumptions do not work (Colander and Su, 2018). The businesses' supply chain models are not effectively maintained based on neoclassical economics. The neoclassical theory's free-market approach is also not sustainable for most companies. It affects their preposition and customer satisfaction because the demands cannot be fulfilled due to humans' rational decision-making (Li et al., 2021c). A specific theoretical framework is established behind renewable energy sources, which are considered the most crucial, effectively lowering $\mathrm{CO}_{2}$ emissions and 
environmental degradation. Concerning APM, the linear relationship between assets and expected return from the market exists, which can help predict the future returns of specific investments (Milonakis, 2012).

Environmental degradation is carried out by the variables which contribute and significantly affect the natural processes. These are known as the environment variables that are affected due to the intervention of human-founded activities that disturb the biological processes (Schmidt and Huenteler, 2016). This has caused deep concerns among the environmentalists as the government's increased funding has significantly reduced environmental degradation (Lee et al., 2017b). Multiple measures are being taken to effectively control environmental degradation and to reverse it to its initial conditions. This provides an important rationale for the studies that have been conducted to reduce climate change. Renewable energy sources have the potential to sufficiently reduce environmental degradation in the future as the public slowly adopt these technologies, consequently increasing their demand (De la Croix and Licandro, 2015). This is possible on practical grounds, but due to government strategies being implemented in the industrial sectors, this may not be possible in the protected time frames. This is because the economic models adopted by governmental institutions such as International Monetary Fund (IMF) have facilitated the public by providing multiple facilities in the market (Pirgmaier, 2017). This corresponds to the fact which is described according to the neoclassical theory. It is mostly criticized by the public and different organizations that contribute effectively in the market to reduce environmental degradation due to $\mathrm{CO}_{2}$ emissions (Colander and Su, 2018; Zhang et al., 2021). It is reported in the study that there is a need for an economic strategy that should not wholly comprehend the existence of the neoclassical economic model.

However, in renewable energy sources, the free-market presence will considerably increase the production and implementation of solar technology, but at the same time, it will significantly put pressure on environmental degradation (Mundaca and Markandya, 2016). This corresponds to the factor that many resources need to be utilized to manufacture solar panels. These resources will eventually deplete over time. For example, in the USA, the raw materials are expected to cease in a few decades, and there will be no choice but to import these materials from other countries. China, for example, has leverage over other countries in terms of resources, but everything has a limit, as reported in previous studies (Al-mulali et al., 2013). Environmental degradation or pollution can be reduced entirely if the government uses a balanced approach to devise the energy sector's economic policies. According to APM, management practices are needed to effectively utilize the resources available to make the renewable energy sector more sustainable (Nawaz et al., 2021a, 2021b, 2021b).

As an independent variable, the efficiency of green growth depends on the resources and technologies employed to limit the use of natural resources expressly (Aziz et al., 2020). The prominent solution devised for effective green growth is solar technology, which can provide more leverage to the governments to solve energy-related issues and make the environment better for everyone, from where the $\mathrm{CO}_{2}$ emissions are continuously rising. Green growth is considered as one of the influential mitigating factors or remedies. It is entirely wrong based on neoclassical economics to think of human nature's emotional responses. According to Solar Technology, there is also a strong relationship between green growth and the public's buying decision. Due to the positive impact of green growth, it is expected that the neoclassical theory to fully comprehend the role of people in effectively increasing the sustainability of solar technology in the future (Ahmed et al., 2019). Solar technology will provide a more sustainable green growth to the economies.

New products are being created daily, and most of them are not environmentally friendly because of the business-based approach used by the manufacturers. A study by bib_Lee_et_al_2017aLee et al., 2017a, 2017b identified that with the recent changes in the climate and environment, it is necessary to create new products that provide environmental sustainability to reduce the factors which are damaging the ecological processes (Lee et al., 2017a). An example of the latest sustainable products and reduce the environmental factors contributing to $\mathrm{CO}_{2}$ emissions or environmental degradation are eco-products manufactured based on eco-innovation (Baloch et al., 2021; Zhuang et al., 2021). From a technological perspective, eco-innovation has significant value in the current environment because of the increasing issues that could threaten humanity's sustainable development in the future (Schmidt and Huenteler, 2016). It affects the rate of $\mathrm{CO}_{2}$ emissions and environmental degradation by removing the factors that create significant damage to the environmental and ecological processes.

From the neoclassical approach, businesses are rapidly manufacturing the products, and governmental institutions make it easy for them to sell more products (Diesing and Diesing, 2019). The free-market analogy used in this theory is effective from the perspective of increasing innovation in products, but at the same time, it must be noted that every innovation happening right now is not environmentally friendly. Studies have shown that there is a need to develop new products that are equally sustainable and provide more control toward the environmental variables that contribute to the degradation (Pirgmaier, 2017). This can be effectively done, as evident in previous studies, by employing strategic management controls. Previously, the lack of management has significantly contributed to lowering the efficiency of new products created to facilitate humanity. From a social perspective, eco-innovation has significant value as it can produce sustainable outcomes if both businesses and people work on implementing sustainable technologies such as solar panels, as evident from recent studies (Aman et al., 2015).

Governments are working to decrease the price of energy per unit and to make it more sustainable for the public and the environment. The environment-related tax was introduced to influence the demand and supply of energy-related products (Sharif et al., 2020). As evident from previous studies, it helps to significantly shape the relative energy prices to maintain the environmental sustainability. Influencing consumer behavior is accepted dramatically in the modern world because of the public's increasing demand and power shortages. Fuel is the best example in which environmental taxes are imposed to influence consumer behavior, and the price varies according to the interest of the government and companies that are selling it. Based on the neoclassical theory, this kind of economics is significantly associated with rational human behavior (Aziz et al., 2020). Governments and companies influence the consumers by effectively altering the prices by imposing multiple taxes, and at the same time, people also buy in a large amount. However, this is from a sustainability perspective (Diesing and Diesing, 2019). From a future perspective, it is expected that consumers' buying behavior will significantly shift due to the government's actions to reduce environmental taxes on the environment's most miniature sustainable products and increase the effects that inflict damage to the ground. According to the neoclassical model, this is again as it will significantly allow the public's conventional buying behavior to be altered (Colander and Su, 2018). According to APM, the pricing model can change considerably based on the consumers' demand, but at the same time, providing more to the consumer is also one of the primary vital concepts considered from an environmental sustainability perspective (APM, 2012).

There are different forms of energy, and from previous studies, it is evident that each has its impact on $\mathrm{CO}_{2}$ emissions and environmental degradation. The world is moving toward a time when energy demand will significantly increase, and the current methods to generate energy are non-renewable and highly detrimental to the environment (Mohsin et al., 2021). As stated earlier, evidence from previous studies' concept of renewable energies has significantly increased over the past two decades because of the increased environmental concern at the governmental and public levels (Al-mulali et al., 2013). Through extensive research and development, multiple methods are available in the market, which are renewable and easily accessible. Solar panels are the most 
effective renewable source present in the market and are sold to facilitate the public. But due to the politics and conflicts between large oil companies, there are significant disapproval toward solar panel energy because it has open a new way to generate electricity without using any natural resources (Schmidt and Huenteler, 2016; Umar et al., 2021). There is a large monopoly in renewable energy from the neoclassical approach as every company and government is trying to use these products to generate more funding or profits. The assumption that human behavior will be rational does not effectively apply, but it is also found to provide more opportunities to the companies to significantly influence consumer behavior (Ahmed et al., 2019).

Economic decision-making is necessary because it dramatically affects the future of any sustainable product, which is solar technology. As recommended by recent studies, behavioral economics is needed to effectively increase the adaptability to renewable energy sources among the public and large scale (Colander and Su, 2018). Although there is a reasonable discussion in the past and recent literature, theoretical and empirical, the nexus between environmental pollution, economic growth, ecological innovation, and environmental taxes with green energy is not very well presented specifically in the USA. This would justify the presence of a literature gap where most of the studies were carried out without considering the dynamic linkage between the above-stated variables. Additionally, the provided literature is also missing some advance and reliable methodological contributions, like in the case of QARDL, which helps to examine the trends in the study variables over low, medium, and higher-level quantiles. Therefore, this study covered this methodological gap while incorporating the QARDL approach to examine the long and short-run trends in two of the outcome variables, $\mathrm{CO}_{2}$ emission and haze pollution (e.g., PM2.5), specifically in the context of the USA.

\section{Research methodology}

In the present study, we have considered the nonlinear association between carbon emission measured as $\mathrm{CO}_{2}$ emission (kt), PM2.5 is measured as the PM2.5 air pollution (percent of total), green growth is measured as the green gas emission (percent change from 1970), environmental taxes are measured as the taxes on the environment (percent of total revenue), ecological innovation is measured as the expenditure on ecological innovation (percent of total expenditures), and the renewable energy consumption is measured as the percentage of energy consumption for the economy of USA. These data have been extracted from the World Bank Indicators (WDI). For this purpose, we have applied the innovative approach, QARDL, while observing the dynamic relationship between the study variables. There are various advantages for the application of QARDL compared to the traditional methods. For example, QARDL helps to consider both long- and short-run estimations with the help of a range of quantiles and the conditional distribution of explained variables (Mensi et al., 2019). Additionally, it also helps to examine the locational asymmetry association between the study variables and the conditional distribution. To check for their robustness, the dependability under each quantile is observed with the help of the Waldtest for both short- and long-term symmetry. In its econometric term, the traditional ARDL model can be expressed with the help of Equation (1).

$$
\begin{aligned}
& C E t=\alpha+\sum_{i=t}^{p} \phi i C E t-i+\sum_{i=0}^{q 1} \omega_{i} P M_{t-1}+\sum_{i=0}^{q 2} \lambda i G G_{t-I}+\sum_{i=0}^{q 3} \theta_{i} E I_{t-I} \\
& \quad+\sum_{i=0}^{q 4} \theta_{i} E R T_{t-I}+\sum_{i=0}^{q 5} \theta_{i} R E N_{t-I}+\varepsilon_{t}
\end{aligned}
$$

Where in the above equation, the term $\varepsilon_{t}$ indicates the error term, and $\mathrm{p}, \mathrm{q} 1$, and $\mathrm{q} 2$ are the lag orders as selected through Schwarz information criteria (SIC). The titles like $\mathrm{Y}$ indicate the main dependent variable and $\mathrm{X} 1$ to $\mathrm{X} 4$ reflect the study's key explanatory variables. In addition, authors like (Chou and Yeh, 2015) have provided an extended form of Equation (1) above while describing the concept of QARDL with the help of Equation (2).

$$
\begin{array}{r}
Q C E_{t}=\alpha(t)+\sum_{i=t}^{p} \phi I(\tau) C E_{t=i}+\sum_{i=0}^{q 1} \omega_{i} P M_{t-1}+\sum_{i=0}^{q 2} \lambda i(\tau) G G_{t-I} \\
+\sum_{i=0}^{q 3} \theta_{I}(\tau) E I_{t-i}+\sum_{i=0}^{q 4} \theta_{I}(\tau) E R T++\sum_{i=0}^{q 5} \theta_{I}(\tau) R E N_{t-i}+\varepsilon_{t}(\tau)
\end{array}
$$

Where in Equation (2), the term $\varepsilon_{t}(\tau)$ indicates the $\pi$ th quantile of $\mathrm{CO}_{2}$ emission and PM2.5. Meanwhile, Equation (2) can be formulated into the following condition as expressed in Equation (3).

$$
\begin{gathered}
\mathrm{Q}_{\mathrm{CE}_{\mathrm{t}}}=\alpha(\tau)+\mathrm{CE}_{\mathrm{t}-\mathrm{i}}+\phi_{1} \mathrm{PM}_{\mathrm{t}-\mathrm{i}}+\phi_{2} \mathrm{GG}_{\mathrm{t}-\mathrm{i}}+\phi_{3} \mathrm{EI}_{\mathrm{t}-\mathrm{i}}+\phi_{4} \mathrm{ERT}_{\mathrm{t}-\mathrm{i}} \\
+\phi_{5} \mathrm{REN}_{\mathrm{t}-\mathrm{i}}+\sum_{\mathrm{i}}^{\mathrm{p}} \beta_{1}(\tau) \mathrm{CE}_{\mathrm{t}-\mathrm{i}}+\sum_{\mathrm{i}}^{\mathrm{q}} \beta_{2}(\tau) \mathrm{PM}_{\mathrm{t}-\mathrm{i}}+\sum_{\mathrm{i}}^{\mathrm{m}} \beta_{3}(\tau) \mathrm{GG}_{\mathrm{t}-\mathrm{i}} \\
+\sum_{\mathrm{i}}^{\mathrm{n}} \beta_{4}(\tau) \mathrm{EI}_{\mathrm{t}-\mathrm{i}}+\sum_{\mathrm{i}}^{\mathrm{r}} \beta_{5}(\tau) \mathrm{ERT}_{\mathrm{t}-\mathrm{i}}+\sum_{\mathrm{i}}^{\mathrm{r}} \beta_{6}(\tau) \operatorname{REN}_{\mathrm{t}-\mathrm{i}}+\varepsilon_{\mathrm{t}}(\tau)
\end{gathered}
$$

After determining the above Equation (3), the following Equation (4) describes the modified form of QARDL based on the error correction model.

$$
\begin{gathered}
\mathrm{Q}_{\mathrm{CE}_{\mathrm{t}}}=\alpha(\tau)+\rho(\tau)\left(\mathrm{CE}_{\mathrm{t}-\mathrm{i}}-\omega_{1}(\tau) \mathrm{PM}_{\mathrm{t}-\mathrm{i}}-\omega_{2}(\tau) \mathrm{GG}_{\mathrm{t}-\mathrm{i}}-\omega_{3}(\tau) \mathrm{EI}_{\mathrm{t}-\mathrm{i}}\right. \\
\left.\left.-\omega_{4}(\tau) \mathrm{ERT}_{\mathrm{t}-\mathrm{i}}\right)-\omega_{1}(\tau) \operatorname{REN}_{\mathrm{t}-\mathrm{i}}\right)+\sum_{\mathrm{i}=1}^{\mathrm{p}-1} \beta_{1}(\tau) \Delta \mathrm{CE}_{\mathrm{t}-\mathrm{i}}+\sum_{\mathrm{i}=0}^{\mathrm{q}-1} \beta_{2}(\tau) \Delta \mathrm{PM}_{\mathrm{t}-\mathrm{i}} \\
+\sum_{\mathrm{i}=0}^{\mathrm{m}-1} \beta_{3}(\tau) \Delta \mathrm{GG}_{\mathrm{t}-\mathrm{i}}+\sum_{\mathrm{i}=0}^{\mathrm{n}-1} \beta_{4}(\tau) \Delta \mathrm{EI}_{\mathrm{t}-\mathrm{i}}+\sum_{\mathrm{i}=0}^{\mathrm{r}-1} \beta_{5}(\tau) \Delta \mathrm{ERT}_{\mathrm{t}-\mathrm{i}}+\sum_{\mathrm{i}=0}^{\mathrm{r}-1} \beta_{6}(\tau) \Delta \mathrm{REN}_{\mathrm{t}-\mathrm{i}} \\
+\varepsilon_{\mathrm{t}}(\tau)
\end{gathered}
$$

\section{Results and discussion}

Descriptive results are provided in Table 1, covering all the study variables as measured through a natural $\log$. The results through mean scores reflected that $\mathrm{CO}_{2}$ emission has the highest mean score among all the variables, followed by haze pollution (i.e., PM2.5). In addition, both environmental pollution dynamics showed maximum scores compared to other study variables. This means that both $\mathrm{CO}_{2}$ emission and PM2.5 have higher trends in the USA than other study variables. However, the green growth and ecological innovation trends were lower than $\mathrm{CO}_{2}$ emission and haze pollution but higher than the environmental taxes and renewable energy. In addition, the result showed that environmental taxes have a mean score of 1.987 and a minimum value of 0.789 . This would justify the argument that although the trends of environmental taxes in the USA are lower than the $\mathrm{CO} 2$ emission and haze pollution, its maximum trend is still higher than the utilization of renewable energy. This means that the government should pay more attention to increasing environmental taxes and renewable energy sources to achieve better environmental outcomes with the increasing $\mathrm{CO} 2$ emission and haze pollution levels. Finally, the results of the J-B test are also presented in Table 1 to justify whether the data for all the study variables is normally distributed (null hypothesis) or not normally

Table 1

Results of descriptive statistics.

\begin{tabular}{llllll}
\hline Variables & Mean & Min. & Max. & Std. Dev. & J-B Stats \\
\hline CE & 9.012 & 8.210 & 10.010 & 0.001 & $16.012^{* * *}$ \\
PM $_{2.5}$ & 7.032 & 6.230 & 8.101 & 0.101 & $34.023^{* * *}$ \\
GG & 5.206 & 4.602 & 6.105 & 1.015 & $20.202^{* * *}$ \\
EI & 3.689 & 2.986 & 4.013 & 1.003 & $14.090^{* * *}$ \\
ERT & 1.987 & 0.789 & 2.011 & 0.010 & $22.010^{* * *}$ \\
REN & 0.963 & 0.036 & 1.100 & 0.030 & $19.413^{* * *}$ \\
\hline
\end{tabular}

Note: $\mathrm{CE}$ means $\mathrm{CO}_{2}$ emissions, PM2.5 means particulate matters 2.5, GG stands for green growth, EI means ecological innovation, ERT means environmental taxes, REN means renewable energy. $* * *, * *$, and * reflects significance level at $1 \%, 5 \%$, and $10 \%$, accordingly. Source: Authors' estimation. 
distributed (alternative hypothesis). The significant values of the J-B test for all the study variables showed that the data were not normally distributed, giving enough evidence to implement methods like QARDL in the present study.

Table 2 shows the results for the unit root test for all the study variables. For a better understanding, the findings are reflected with the help of ADF (level), ADF $(\Delta)$, ZA (Level), and ZA $(\Delta)$. One of the significant benefits of applying the ZA test compared to ADF is that it accounts for the structural breaks in the study data. The ZA and ADF test results have confirmed that at I (1), all the study variables data were stationary at $1 \%$ and $5 \%$ significance levels. This would justify the argument that the study variables have their special order or integration, known as I (1).

After analyzing the descriptive scores and unit root test outcomes, Table 3 shows the outcomes for the QARDL for both the long- and shortrun equilibrium. The results in Table 3 confirmed that the estimated speed of adjustment coefficient as reflected through p* was observed as negative and significant for the lower-order and medium-order quantiles. This would justify the argument that there is a presence of reversion to long-run equilibrium among the study variables such as $\mathrm{CO}_{2}$ emission, PM2.5, green growth, ecological environment, environmental taxes, and renewable energy for the economy of the USA. More specifically, the speed of adjustment was the highest for the 0.40th quantile, with a score of -0.284 , at a $5 \%$ significance level. In addition, the results showed that the impact of green growth on $\mathrm{CO}_{2}$ emission from the 0.20 th quantile to 0.95 th was negatively significant at $5 \%$. This would justify that higher green growth in the economy of the USA tends to create an adverse impact on $\mathrm{CO}_{2}$ emission, hence lowering the environmental pollution under the long-run estimation. In recent times, Hao et al. (2021) have provided their theoretical and empirical justification for analyzing the relationship between green growth and $\mathrm{CO}_{2}$ emissions among G7 countries. The outcomes of theoretical and empirical findings have justified the argument that both linear and nonlinear terms of green growth in the targeted economies lower $\mathrm{CO}_{2}$ emissions. This would explain the present study results where a negative and significant association between green growth and $\mathrm{CO}_{2}$ emissions was found. In addition, the findings in Table 3 specify that the square of GG also confirmed its significant and negative relationship with $\mathrm{CO}_{2}$ emissions but only for the lower-order and medium-order quantiles. This shows that higher green growth is a good sign in lowering $\mathrm{CO}_{2}$ emissions in the USA. Furthermore, ecological innovation's significant and negative impact on $\mathrm{CO}_{2}$ emissions was observed for the medium and higher-order quantiles. This means that the ecological innovation reasonably controls the adverse impact of $\mathrm{CO}_{2}$ emissions in the USA during the study period. In this regard (Hashmi and Alam, 2019), have contributed significantly to the present literature while exploring the relationship between ecological innovation and $\mathrm{CO}_{2}$ emission (Ding et al., 2021). have also expressed their view that the role of ecological innovation in consumption-based $\mathrm{CO} 2$ emissions is quite significant to consider, among other variables. However, the role of environmental taxes in lowering the $\mathrm{CO}_{2}$ emissions for the USA's economy was only observed for the higher-order quantiles during the long-run estimation of this study. From the perspective of Hao et al. (2021), they claimed that the role of environmental taxes in improving the natural environment from $\mathrm{CO}_{2}$ emissions is evident, specifically for the G7 economies. Lastly, the long-run estimation in Table 3 has confirmed a significant and negative role of renewable energy in lowering $\mathrm{CO} 2$ emissions in the USA. Various studies have explored the dynamic role of renewable energy sources in reducing $\mathrm{CO}_{2}$ emissions. For instance (Yao et al., 2019), provided empirical evidence that a $10 \%$ increase in the value of renewable energy would lead to a $1.6 \%$ reduction in $\mathrm{CO}_{2}$ emission (Liu et al., 2017). indicated that the increasing trends in renewable energy and agriculture decrease $\mathrm{CO}_{2}$ emissions (Kahia et al., 2019). have also provided similar evidence while claiming that a higher level of renewable energy consumption can lower $\mathrm{CO}_{2}$ emissions in 12 MENA countries.

Table 3 also shows the short-run estimation results where it was found that past and lagged values of $\mathrm{CO}_{2}$ emissions were negatively and significantly linked with the current and lagged values of $\mathrm{CO}_{2}$ emissions. However, this fact was only justified under lower-order and higher quantiles. The highest negative effect was observed for the lower-order quantiles and the lowest for higher-order quantiles. More specifically, this relationship was observed as significant and negative for the lowerorder and higher-order quantiles (0.70th and 0.80th) for GG and $\mathrm{CO}_{2}$ emissions. Lastly, the past and lagged values of REN were found to be significantly and negatively linked with the current and lagged values of $\mathrm{CO}_{2}$ emissions but only for the lower-order and medium-order quantiles.

Like Table 3, the findings for both long and short estimations with the help of QARDL, specifically for PM2.5, are provided in Table 4. Initially, we examined the outcomes for the speed of adjustment coefficient as reflected through $\mathrm{p}^{*}$, which showed negative and significant results. However, the speed of adjustment coefficient was only significant from the 0.05 th quantile to 0.70 th quantile. This means that there is a reversion of long-run equilibrium among the green growth, square of green growth, ecological innovation, environmental taxes, renewable energy, and haze pollution like PM2.5. In addition, the findings also justified the fact that green growth is putting good pressure on lowering the haze pollution like PM2.5 in the natural environment of the USA. However, the highest impact was observed for the 0.20th quantile, with a score of -0.450 , at a $1 \%$ significance level. Nevertheless, the square of green growth was significant and a negative determinant of PM2.5 but only for the lower-order quantiles (Nguyen et al, 2015, 2021). have given their views, claiming that green growth in the form of urban forest systems can capture and store dust from the natural environment.

In addition, our results confirmed that environmental taxes are a good sign in reducing particulate pollution in the natural environment. However, this fact was only observed for the higher-order quantiles, as shown in Table 4. Morley (2012) claimed that environmental taxes were significant in lowering air pollution. Lastly, the long-run estimation findings showed that renewable energy is also a good indicator towards reducing particulate haze pollution in the USA. This fact was observed in Table 4, where the coefficients were observed as negative and significant for most of the quantiles, except for the last two. This indicates that promoting renewable sources can be a good sign in providing a better natural environment with a low level of haze pollution like PM2.5. In

Table 2

Results of unit root test.

\begin{tabular}{|c|c|c|c|c|c|c|}
\hline Variables & ADF (Level) & $\operatorname{ADF}(\Delta)$ & ZA (Level) & Break Year & $\mathrm{ZA}(\Delta)$ & Break Year \\
\hline CE & -0.287 & $-4.148^{* * *}$ & -1.107 & 2015 Q1 & $-9.015^{* * *}$ & 2004 Q1 \\
\hline $\mathbf{P M}_{2.5}$ & -1.074 & $-4.399 * * *$ & -0.541 & 2010 Q2 & $-8.374^{* * *}$ & 2009 Q2 \\
\hline GG & -0.435 & $-5.361 * * *$ & -0.398 & 2016 Q4 & $-11.100^{* * *}$ & 2011 Q1 \\
\hline EI & -0.879 & $-11.357^{* * *}$ & -1.011 & 2008 Q1 & $-14.716^{* * *}$ & 2013 Q1 \\
\hline ERT & -0.984 & $-5.781 * * *$ & -1.417 & 2014 Q1 & $-7.158^{* * *}$ & 2016 Q1 \\
\hline REN & -1.147 & $-4.891 * * *$ & -0.177 & 2017 Q1 & $-8.556^{* * *}$ & 2010 Q4 \\
\hline
\end{tabular}

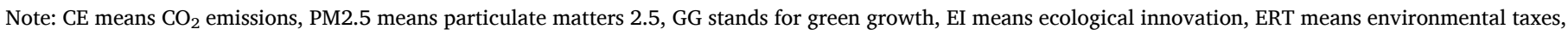

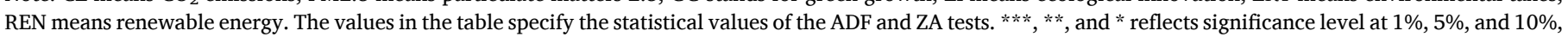
accordingly.

Source: Authors' estimation. 
Table 3

Results of quantile autoregressive distributed lag (QARDL) for $\mathrm{CO}_{2}$ emission.

\begin{tabular}{|c|c|c|c|c|c|c|c|c|c|c|c|c|c|}
\hline $\begin{array}{l}\text { Quantiles } \\
(\tau)\end{array}$ & $\alpha_{*}(\tau)$ & $\rho_{*}(\tau)$ & $\beta_{\mathrm{GG}}(\tau)$ & $\beta_{\mathrm{GG} 2}(\tau)$ & $\beta_{\mathrm{EI}}(\tau)$ & $\beta_{\mathrm{ERT}}(\tau)$ & $\beta_{\mathrm{REN}}(\tau)$ & $\phi_{1}(\tau)$ & $\omega_{0}(\tau)$ & $\lambda_{0}(\tau)$ & $\theta_{0}(\tau)$ & $\dot{\varepsilon}_{0}(\tau)$ & $\delta_{0}(\tau)$ \\
\hline 0.05 & $\begin{array}{l}0.020 \\
(0.101)\end{array}$ & $\begin{array}{l}-0.224^{* * *} \\
(-4.924)\end{array}$ & $\begin{array}{l}-0.130 \\
(-0.810)\end{array}$ & $\begin{array}{l}-0.170^{* * *} \\
(-3.007)\end{array}$ & $\begin{array}{l}-0.100 \\
(-0.009)\end{array}$ & $\begin{array}{l}-0.103 \\
(-0.001)\end{array}$ & $\begin{array}{l}-0.243^{* * *} \\
(-3.003)\end{array}$ & $\begin{array}{l}-0.345^{* * * *} \\
(-4.054)\end{array}$ & $\begin{array}{l}-0.087^{*} \\
(-1.789)\end{array}$ & $\begin{array}{l}-0.007 \\
(-0.107)\end{array}$ & $\begin{array}{l}-0.089^{* * *} \\
(-5.987)\end{array}$ & $\begin{array}{l}-0.013 \\
(-0.030)\end{array}$ & $\begin{array}{l}-0.087^{* * *} \\
(-6.789)\end{array}$ \\
\hline 0.10 & $\begin{array}{l}0.030 \\
(0.013)\end{array}$ & $\begin{array}{l}-0.223^{* * *} \\
(-5.238)\end{array}$ & $\begin{array}{l}-0.120 \\
(-1.021)\end{array}$ & $\begin{array}{l}-0.187^{* * *} \\
(-4.078)\end{array}$ & $\begin{array}{l}-0.010 \\
(-0.020)\end{array}$ & $\begin{array}{l}-0.101 \\
(-0.009)\end{array}$ & $\begin{array}{l}-0.332^{* * *} \\
(-4.006)\end{array}$ & $\begin{array}{l}-0.361^{* * *} \\
(-4.001)\end{array}$ & $\begin{array}{l}-0.054^{*} \\
(-1.654)\end{array}$ & $\begin{array}{l}-0.010 \\
(-0.022)\end{array}$ & $\begin{array}{l}-0.054 * * * \\
(-4.456)\end{array}$ & $\begin{array}{l}-0.011 \\
(-0.105)\end{array}$ & $\begin{array}{l}-0.098^{* * * *} \\
(-4.098)\end{array}$ \\
\hline 0.20 & $\begin{array}{l}0.040 \\
(0.014)\end{array}$ & $\begin{array}{l}-0.228^{* * * *} \\
(-4.827)\end{array}$ & $\begin{array}{l}-0.121^{* *} \\
(-2.010)\end{array}$ & $\begin{array}{l}-0.173^{\text {***** }} \\
(-4.037)\end{array}$ & $\begin{array}{l}-0.013 \\
(-0.130)\end{array}$ & $\begin{array}{l}-0.107 \\
(-0.017)\end{array}$ & $\begin{array}{l}-0.398^{* * * *} \\
(-3.809)\end{array}$ & $\begin{array}{l}-0.150 \\
(-0.005)\end{array}$ & $\begin{array}{l}-0.080^{* * * *} \\
(-5.088)\end{array}$ & $\begin{array}{l}-0.090 \\
(-0.009)\end{array}$ & $\begin{array}{l}-0.082^{* * * *} \\
(-3.852)\end{array}$ & $\begin{array}{l}-0.041 \\
(-0.031)\end{array}$ & $\begin{array}{l}-0.046 * * \\
(-2.010)\end{array}$ \\
\hline 0.30 & $\begin{array}{l}0.102 \\
(0.201)\end{array}$ & $\begin{array}{l}-0.232^{* *} \\
(-2.108)\end{array}$ & $\begin{array}{l}-0.402^{* *} \\
(-1.752)\end{array}$ & $\begin{array}{l}-0.102^{* *} \\
(-2.002)\end{array}$ & $\begin{array}{l}-0.025 \\
(-0.205)\end{array}$ & $\begin{array}{l}-0.062 \\
(-0.012)\end{array}$ & $\begin{array}{l}-0.357^{* * *} \\
(-2.075)\end{array}$ & $\begin{array}{l}-0.130 \\
(-0.070)\end{array}$ & $\begin{array}{l}-0.061^{* * * *} \\
(-4.110)\end{array}$ & $\begin{array}{l}-0.058 \\
(-0.003)\end{array}$ & $\begin{array}{l}-0.057^{* *} \\
(-2.035)\end{array}$ & $\begin{array}{l}-0.029 \\
(-0.308)\end{array}$ & $\begin{array}{l}-0.039^{* * *} \\
(-2.030)\end{array}$ \\
\hline 0.40 & $\begin{array}{l}0.001 \\
(0.010)\end{array}$ & $\begin{array}{l}-0.284^{* *} \\
(-2.074)\end{array}$ & $\begin{array}{l}-0.361^{* *} \\
(-2.061)\end{array}$ & $\begin{array}{l}-0.110^{* * *} \\
(-2.040)\end{array}$ & $\begin{array}{l}-0.225^{*} \\
(-1.825)\end{array}$ & $\begin{array}{l}-0.051 \\
(-0.079)\end{array}$ & $\begin{array}{l}-0.367^{* *} \\
(-1.967)\end{array}$ & $\begin{array}{l}-0.189 \\
(-1.029)\end{array}$ & $\begin{array}{l}-0.053 \\
(-0.001)\end{array}$ & $\begin{array}{l}-0.066 \\
(0.006)\end{array}$ & $\begin{array}{l}-0.098 \\
(-0.131)\end{array}$ & $\begin{array}{l}-0.039 \\
(-0.090)\end{array}$ & $\begin{array}{l}-0.011^{* *} \\
(-2.006)\end{array}$ \\
\hline 0.50 & $\begin{array}{l}0.103 \\
(0.130)\end{array}$ & $\begin{array}{l}-0.226^{* *} \\
(-1.999)\end{array}$ & $\begin{array}{l}-0.342^{* * * *} \\
(-4.246)\end{array}$ & $\begin{array}{l}-0.102 \\
(-0.020)\end{array}$ & $\begin{array}{l}-0.116^{*} \\
(-1.761)\end{array}$ & $\begin{array}{l}-0.109 \\
(-0.190)\end{array}$ & $\begin{array}{l}-0.383^{* *} \\
(-1.938)\end{array}$ & $\begin{array}{l}-0.109 \\
(-1.007)\end{array}$ & $\begin{array}{l}-0.040 \\
(-0.041)\end{array}$ & $\begin{array}{l}-0.004 \\
(-0.014)\end{array}$ & $\begin{array}{l}-0.011 \\
(-0.001)\end{array}$ & $\begin{array}{l}-0.021 \\
(-0.010)\end{array}$ & $\begin{array}{l}-0.012 \\
(-1.071)\end{array}$ \\
\hline 0.60 & $\begin{array}{l}0.105 \\
(0.050)\end{array}$ & $\begin{array}{l}-0.212^{*} \\
(-1.712)\end{array}$ & $\begin{array}{l}-0.328^{* * *} \\
(-5.028)\end{array}$ & $\begin{array}{l}-0.120 \\
(-1.002)\end{array}$ & $\begin{array}{l}-0.200^{* *} \\
(-2.007)\end{array}$ & $\begin{array}{l}-0.014 \\
(-0.404)\end{array}$ & $\begin{array}{l}-0.312^{*} \\
(-1.721)\end{array}$ & $\begin{array}{l}-0.134 \\
(-0.432)\end{array}$ & $\begin{array}{l}-0.068 \\
(-1.068)\end{array}$ & $\begin{array}{l}-0.013 \\
(-0.008)\end{array}$ & $\begin{array}{l}-0.051 \\
(-0.015)\end{array}$ & $\begin{array}{l}-0.024 \\
(-0.140)\end{array}$ & $\begin{array}{l}-0.047 \\
(-0.013)\end{array}$ \\
\hline 0.70 & $\begin{array}{l}0.107 \\
(0.070)\end{array}$ & $\begin{array}{l}-0.225^{*} \\
(-1.752)\end{array}$ & $\begin{array}{l}-0.282^{* * * *} \\
(-6.028)\end{array}$ & $\begin{array}{l}-0.104 \\
(-1.004)\end{array}$ & $\begin{array}{l}-0.234^{* *} \\
(-2.934)\end{array}$ & $\begin{array}{l}-0.110 \\
(-1.211)\end{array}$ & $\begin{array}{l}-0.247^{*} \\
(-1.874)\end{array}$ & $\begin{array}{l}-0.102 \\
(-0.040)\end{array}$ & $\begin{array}{l}-0.066^{* *} \\
(-2.066)\end{array}$ & $\begin{array}{l}-0.057 \\
(-0.053)\end{array}$ & $\begin{array}{l}-0.037 \\
(-1.003)\end{array}$ & $\begin{array}{l}-0.052 \\
(-0.005)\end{array}$ & $\begin{array}{l}-0.028 \\
(-0.018)\end{array}$ \\
\hline 0.80 & $\begin{array}{l}0.110 \\
(0.0123)\end{array}$ & -0.110 & $\begin{array}{l}-0.313^{* * * *} \\
(-5.030)\end{array}$ & $\begin{array}{l}-0.001 \\
(-1.101)\end{array}$ & $\begin{array}{l}-0.156^{* * * *} \\
(-4.056)\end{array}$ & $\begin{array}{l}-0.124 * * \\
(-2.041)\end{array}$ & $\begin{array}{l}-0.218^{*} \\
(-1.800)\end{array}$ & $\begin{array}{l}-0.273^{*} \\
(-1.736)\end{array}$ & $\begin{array}{l}-0.077^{* *} \\
(-2.044)\end{array}$ & $\begin{array}{l}-0.101 \\
(-0.102)\end{array}$ & $\begin{array}{l}-0.018 \\
(-1.017)\end{array}$ & $\begin{array}{l}-0.081 \\
(-1.018)\end{array}$ & $\begin{array}{l}-0.010 \\
(-1.010)\end{array}$ \\
\hline 0.90 & $\begin{array}{l}0.021 \\
(0.012)\end{array}$ & $\begin{array}{l}-0.103 \\
(-1.003)\end{array}$ & $\begin{array}{l}-0.322^{* * *} \\
(-4.022)\end{array}$ & $\begin{array}{l}-0.123 \\
(-1.321)\end{array}$ & $\begin{array}{l}-0.212^{* * *} \\
(-3.912)\end{array}$ & $\begin{array}{l}-0.243^{* *} \\
(-2.103)\end{array}$ & $\begin{array}{l}-0.190 \\
(-1.007)\end{array}$ & $\begin{array}{l}-0.198^{*} \\
(-1.098)\end{array}$ & $\begin{array}{l}-0.061 \\
(-0.011)\end{array}$ & $\begin{array}{l}-0.067 \\
(-0.017)\end{array}$ & $\begin{array}{l}-0.061 \\
(-0.014)\end{array}$ & $\begin{array}{l}-0.032 \\
(-1.002)\end{array}$ & $\begin{array}{l}-0.003 \\
(-1.301)\end{array}$ \\
\hline 0.95 & $\begin{array}{l}0.007 \\
(0.017)\end{array}$ & $\begin{array}{l}-0.130 \\
(-0.300)\end{array}$ & $\begin{array}{l}-0.233^{* * *} \\
(-3.033)\end{array}$ & $\begin{array}{l}-0.060 \\
(-1.016)\end{array}$ & $\begin{array}{l}-0.205^{* * *} \\
(-3.055)\end{array}$ & $\begin{array}{l}-0.381^{* * *} \\
(-3.008)\end{array}$ & $\begin{array}{l}-0.103 \\
(-1.100)\end{array}$ & $\begin{array}{l}-0.177^{*} \\
(-1.777)\end{array}$ & $\begin{array}{l}-0.080 \\
(-1.008)\end{array}$ & $\begin{array}{l}-0.077 \\
(-0.070)\end{array}$ & $\begin{array}{l}-0.009 \\
(-0.070)\end{array}$ & $\begin{array}{l}-0.087 \\
(-1.070)\end{array}$ & $\begin{array}{l}-0.040 \\
(-1.020)\end{array}$ \\
\hline
\end{tabular}

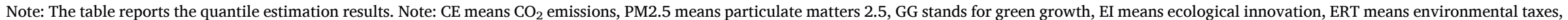
REN means renewable energy. $* * *, * *$, and * reflects significance level at $1 \%, 5 \%$, and $10 \%$, accordingly. Source: Authors' estimations.

Table 4

Results of quantile autoregressive distributed lag (QARDL) for $\mathrm{PM}_{2.5}$.

\begin{tabular}{|c|c|c|c|c|c|c|c|c|c|c|c|c|c|}
\hline $\begin{array}{l}\text { Quantiles } \\
(\tau)\end{array}$ & $\alpha_{*}(\tau)$ & $\rho *(\tau)$ & $\beta_{\mathrm{GG}}(\tau)$ & $\beta_{\mathrm{GG} 2}(\tau)$ & $\beta_{\mathrm{EI}}(\tau)$ & $\beta_{\mathrm{ERT}}(\tau)$ & $\beta_{\mathrm{REN}}(\tau)$ & $\phi_{1}(\tau)$ & $\omega_{0}(\tau)$ & $\lambda_{0}(\tau)$ & $\theta_{0}(\tau)$ & $\dot{\varepsilon}_{0}(\tau)$ & $\delta_{0}(\tau)$ \\
\hline 0.05 & $\begin{array}{l}0.212 \\
(0.010)\end{array}$ & $\begin{array}{l}-0.221^{* * * *} \\
(-6.012)\end{array}$ & $\begin{array}{l}-0.270 \\
(-0.050)\end{array}$ & $\begin{array}{l}-0.167^{* * * k} \\
(-5.076)\end{array}$ & $\begin{array}{l}-0.110 \\
(-0.011)\end{array}$ & $\begin{array}{l}-0.001 \\
(-0.100)\end{array}$ & $\begin{array}{l}-0.479^{* * * *} \\
(-6.789)\end{array}$ & $\begin{array}{l}-0.547^{* * * *} \\
(-3.147)\end{array}$ & $\begin{array}{l}-0.389^{*} \\
(-1.683)\end{array}$ & $\begin{array}{l}-0.026 \\
(-0.001)\end{array}$ & $\begin{array}{l}-0.079 * * * \\
(-3.009)\end{array}$ & $\begin{array}{l}-0.010 \\
(-0.300)\end{array}$ & $\begin{array}{l}-0.248^{* * * *} \\
(-4.346)\end{array}$ \\
\hline 0.10 & $\begin{array}{l}0.313 \\
(0.010)\end{array}$ & $\begin{array}{l}-0.261^{* * *} \\
(-5.010)\end{array}$ & $\begin{array}{l}-0.231 \\
(-0.021)\end{array}$ & $\begin{array}{l}-0.126^{* * *} \\
(-5.062)\end{array}$ & $\begin{array}{l}-0.116 \\
(-0.160)\end{array}$ & $\begin{array}{l}-0.021 \\
(-0.010)\end{array}$ & $\begin{array}{l}-0.410^{* * *} \\
(-5.008)\end{array}$ & $\begin{array}{l}-0.499 * * * \\
(-3.109)\end{array}$ & $\begin{array}{l}-0.410^{*} \\
(-1.654)\end{array}$ & $\begin{array}{l}-0.058 \\
(-0.008)\end{array}$ & $\begin{array}{l}-0.066 * * * \\
(-3.046)\end{array}$ & $\begin{array}{l}-0.021 \\
(-0.002)\end{array}$ & $\begin{array}{l}-0.159^{* * *} \\
(-5.591)\end{array}$ \\
\hline 0.20 & $\begin{array}{l}0.055 \\
(0.031)\end{array}$ & $\begin{array}{l}-0.294^{* * * *} \\
(-4.194)\end{array}$ & $\begin{array}{l}-0.450 * * \\
(-2.001)\end{array}$ & $\begin{array}{l}-0.175^{* * * *} \\
(-4.057)\end{array}$ & $\begin{array}{l}-0.130 \\
(-0.131)\end{array}$ & $\begin{array}{l}-0.107 \\
(-0.071)\end{array}$ & $\begin{array}{l}-0.400^{* * * *} \\
(-4.077)\end{array}$ & $\begin{array}{l}-0.305 \\
(-0.001)\end{array}$ & $\begin{array}{l}-0.901 * * * \\
(-7.091)\end{array}$ & $\begin{array}{l}-0.023 \\
(-0.030)\end{array}$ & $\begin{array}{l}-0.072^{* * *} \\
(-5.002)\end{array}$ & $\begin{array}{l}-0.033 \\
(-0.033)\end{array}$ & $\begin{array}{l}-0.125^{* *} \\
(-2.025)\end{array}$ \\
\hline 0.30 & $\begin{array}{l}0.011 \\
(0.100)\end{array}$ & $\begin{array}{l}-0.221^{* *} \\
(-2.010)\end{array}$ & $\begin{array}{l}-0.321 * * \\
(-2.002)\end{array}$ & $\begin{array}{l}-0.122^{* *} \\
(-2.002)\end{array}$ & $\begin{array}{l}-0.257 \\
(-0.102)\end{array}$ & $\begin{array}{l}-0.002 \\
(-0.101)\end{array}$ & $\begin{array}{l}-0.420^{* *} \\
(-2.040)\end{array}$ & $\begin{array}{l}-0.361 \\
(-0.016)\end{array}$ & $\begin{array}{l}-0.711^{* * * *} \\
(-5.007)\end{array}$ & $\begin{array}{l}-0.021 \\
(-0.012)\end{array}$ & $\begin{array}{l}-0.016^{* * *} \\
(-2.101)\end{array}$ & $\begin{array}{l}-0.077 \\
(-0.200)\end{array}$ & $\begin{array}{l}-0.125^{* *} \\
(-2.005)\end{array}$ \\
\hline 0.40 & $\begin{array}{l}0.084 \\
(0.004)\end{array}$ & $\begin{array}{l}-0.245^{* *} \\
(-2.054)\end{array}$ & $\begin{array}{l}-0.202^{* *} \\
(-2.020)\end{array}$ & $\begin{array}{l}-0.155^{* *} \\
(-2.015)\end{array}$ & $\begin{array}{l}-0.255^{*} \\
(-1.701)\end{array}$ & $\begin{array}{l}-0.009 \\
(-0.010)\end{array}$ & $\begin{array}{l}-0.450 * * \\
(-2.950)\end{array}$ & $\begin{array}{l}-0.219 \\
(-1.011)\end{array}$ & $\begin{array}{l}-0.031 \\
(-0.035)\end{array}$ & $\begin{array}{l}-0.041 \\
(0.004)\end{array}$ & $\begin{array}{l}-0.064 \\
(-0.104)\end{array}$ & $\begin{array}{l}-0.050 \\
(-0.006)\end{array}$ & $\begin{array}{l}-0.170^{* *} \\
(-2.006)\end{array}$ \\
\hline 0.50 & $\begin{array}{l}0.075 \\
(0.050)\end{array}$ & $\begin{array}{l}-0.221 \text { ** } \\
(-2.041)\end{array}$ & $\begin{array}{l}-0.290^{* * * *} \\
(-4.069)\end{array}$ & $\begin{array}{l}-0.133 \\
(-0.103)\end{array}$ & $\begin{array}{l}-0.244^{*} \\
(-1.655)\end{array}$ & $\begin{array}{l}-0.369 \\
(-0.301)\end{array}$ & $\begin{array}{l}-0.390^{* *} \\
(-2.940)\end{array}$ & $\begin{array}{l}-0.262 \\
(-0.026)\end{array}$ & $\begin{array}{l}-0.002 \\
(-0.102)\end{array}$ & $\begin{array}{l}-0.030 \\
(-0.001)\end{array}$ & $\begin{array}{l}-0.026 \\
(-0.031)\end{array}$ & $\begin{array}{l}-0.019 \\
(-0.091)\end{array}$ & $\begin{array}{l}-0.052 \\
(-0.005)\end{array}$ \\
\hline 0.60 & $\begin{array}{l}0.001 \\
(0.003)\end{array}$ & $\begin{array}{l}-0.212^{*} \\
(-1.165)\end{array}$ & $\begin{array}{l}-0.277^{* * * *} \\
(-5.077)\end{array}$ & $\begin{array}{l}-0.120 \\
(-0.010)\end{array}$ & $\begin{array}{l}-0.250 * * \\
(-2.010)\end{array}$ & $\begin{array}{l}-0.110 \\
(-0.211)\end{array}$ & $\begin{array}{l}-0.407^{*} \\
(-1.700)\end{array}$ & $\begin{array}{l}-0.254 \\
(-0.005)\end{array}$ & $\begin{array}{l}-0.159 \\
(-1.115)\end{array}$ & $\begin{array}{l}-0.044 \\
(-0.002)\end{array}$ & $\begin{array}{l}-0.075 \\
(-0.005)\end{array}$ & $\begin{array}{l}-0.050 \\
(-0.010)\end{array}$ & $\begin{array}{l}-0.088 \\
(-0.318)\end{array}$ \\
\hline 0.70 & $\begin{array}{l}0.002 \\
(0.200)\end{array}$ & $\begin{array}{l}-0.271^{*} \\
(-1.731)\end{array}$ & $\begin{array}{l}-0.252^{* * *} \\
(-6.025)\end{array}$ & $\begin{array}{l}-0.119 \\
(-0.019)\end{array}$ & $\begin{array}{l}-0.260^{* * *} \\
(-2.060)\end{array}$ & $\begin{array}{l}-0.107 \\
(-0.237)\end{array}$ & $\begin{array}{l}-0.421^{*} \\
(-1.833)\end{array}$ & $\begin{array}{l}-0.227 \\
(-0.013)\end{array}$ & $\begin{array}{l}-0.654^{* *} \\
(-2.006)\end{array}$ & $\begin{array}{l}-0.101 \\
(-0.010)\end{array}$ & $\begin{array}{l}-0.020 \\
(-1.001)\end{array}$ & $\begin{array}{l}-0.029 \\
(-0.101)\end{array}$ & $\begin{array}{l}-0.047 \\
(-0.001)\end{array}$ \\
\hline 0.80 & $\begin{array}{l}0.009 \\
(0.001)\end{array}$ & $\begin{array}{l}-0.110 \\
(-0.019)\end{array}$ & $\begin{array}{l}-0.253^{* * * *} \\
(-5.075)\end{array}$ & $\begin{array}{l}-0.055 \\
(-0.205)\end{array}$ & $\begin{array}{l}-0.257^{* * *} \\
(-5.007)\end{array}$ & $\begin{array}{l}-0.300^{*} \\
(-1.803)\end{array}$ & $\begin{array}{l}-0.422^{*} \\
(-1.722)\end{array}$ & $\begin{array}{l}-0.390^{*} \\
(-1.901)\end{array}$ & $\begin{array}{l}-0.511^{* *} \\
(-2.011)\end{array}$ & $\begin{array}{l}-0.031 \\
(-0.021)\end{array}$ & $\begin{array}{l}-0.050 \\
(-1.250)\end{array}$ & $\begin{array}{l}-0.070 \\
(-1.100)\end{array}$ & $\begin{array}{l}-0.042 \\
(-1.001)\end{array}$ \\
\hline 0.90 & $\begin{array}{l}0.371 \\
(0.103)\end{array}$ & $\begin{array}{l}-0.114 \\
(-0.004)\end{array}$ & $\begin{array}{l}-0.251^{* * * *} \\
(-4.051)\end{array}$ & $\begin{array}{l}-0.010 \\
(-0.009)\end{array}$ & $\begin{array}{l}-0.288^{* \cdots * *} \\
(-6.080)\end{array}$ & $\begin{array}{l}-0.456^{* * *} \\
(-2.145)\end{array}$ & $\begin{array}{l}-0.201 \\
(-1.090)\end{array}$ & $\begin{array}{l}-0.377^{*} \\
(-1.707)\end{array}$ & $\begin{array}{l}-0.473 \\
(-0.040)\end{array}$ & $\begin{array}{l}-0.061 \\
(-0.0306)\end{array}$ & $\begin{array}{l}-0.087 \\
(-0.007)\end{array}$ & $\begin{array}{l}-0.080 \\
(-1.106)\end{array}$ & $\begin{array}{l}-0.026 \\
(-1.006)\end{array}$ \\
\hline 0.95 & $\begin{array}{l}0.101 \\
(0.011)\end{array}$ & $\begin{array}{l}-0.150 \\
(-0.015)\end{array}$ & $\begin{array}{l}-0.272^{* * * *} \\
(-3.002)\end{array}$ & $\begin{array}{l}-0.018 \\
(-0.108)\end{array}$ & $\begin{array}{l}-0.319^{* * * *} \\
(-7.999)\end{array}$ & $\begin{array}{l}-0.345^{* *} \\
(-2.035)\end{array}$ & $\begin{array}{l}-0.109 \\
(-1.010)\end{array}$ & $\begin{array}{l}-0.431^{*} \\
(-1.731)\end{array}$ & $\begin{array}{l}-0.551 \\
(-1.101)\end{array}$ & $\begin{array}{l}-0.028 \\
(-0.008)\end{array}$ & $\begin{array}{l}-0.044 \\
(-0.004)\end{array}$ & $\begin{array}{l}-0.010 \\
(-1.109)\end{array}$ & $\begin{array}{l}-0.011 \\
(-1.211)\end{array}$ \\
\hline
\end{tabular}

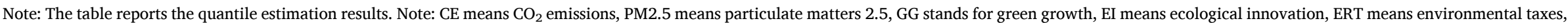
REN means renewable energy. ******, and * reflects significance level at $1 \%, 5 \%$, and $10 \%$, accordingly.

Source: Authors' estimations. 
addition, the findings for the short-term estimation specified that past and lagged values of PM2.5 were significantly and negatively linked with the current and lagged values of PM2.5. Additionally, the relationship between lagged and past values of green growth and EI were also associated with the current and lagged values of PM2.5. However, the impact of past and lagged values of REN on PM2.5 was negatively significant but only for the lower-order and medium-order quantiles.

In addition, Table 5 shows the Wald test's results for the constancy of the parameters for both environmental pollution indicators; $\mathrm{CO}_{2}$ emissions and haze pollution in the form of PM2.5. The null hypothesis for the Wald test in terms of parameter constancy of the adjustment speed is rejected at a $1 \%$ significance level. Furthermore, the null hypothesis of the linearity across different tails of the study quantiles for the variables is also rejected. Thus, it can be inferred that there is a presence of dynamics among different study quantiles for the variables like green growth, the square of green growth, ecological innovation, environmental taxes, and renewable energy consumption in the USA. Similarly, the Wald test findings also provide a significant output for the short-run estimation. This would justify the argument that green growth, the square of green growth, ecological innovation, environmental taxes, and renewable energy have a nonlinear contemporaneous effect on $\mathrm{CO}_{2}$ emissions and haze pollution like PM2.5.

Lastly, Table 6 shows the p-values of the Granger-causality in the quantile test outcomes. The results showed that there is bidirectional causality between the study variables in the USA. The findings indicate a two-way causality between $\mathrm{CO}_{2}$ emission and (1) green growth, (2) ecological innovation, (3) environmental taxes, and (4) renewable energy. Additionally, the study findings justified the two-way causality between PM2.5 and (1) green growth, (2) environmental taxes, (3) ecological innovation, and (4) renewable energy as shown in Table 6.

\section{Discussions, conclusion, and policy implications}

This study found that green growth has a positive association with the environmental condition of the country and is similar to the results of (Chien et al., 2021b) and Chien, Kamran, et al. (2021), who also exposed that green finance, such as renewable energy, has a positive impact on the environmental conditions. In addition, the results also exposed that the environmental-related tax significantly improves the environmental condition of the country, and this matched with the outcomes of (Othman et al., 2020), who also found that the environmental-related measures have a positive impact on the environmental condition of the country. Lastly, the results also unveiled that eco-innovation was significantly related to the environmental conditions, which is in line with the results of (Chien et al., 2021d), who also discovered that innovation in technology could play a positive role on

Table 5

Results of the wald test for the constancy of parameters.

\begin{tabular}{lll}
\hline Variables & Wald-statistics $\left[\mathrm{CO}_{2}\right.$ Emission] & Wald-statistics $\left[\mathrm{PM}_{2.5}\right]$ \\
\hline $\mathbf{P}$ & $9.315^{* * *}(0.000)$ & $11.417^{* * *}(0.000)$ \\
$\boldsymbol{\beta}_{\mathrm{GG}}$ & $24.368^{* * *}(0.000)$ & $34.118^{* * *}(0.000)$ \\
$\boldsymbol{\beta}_{\mathrm{GG} 2}$ & $16.087^{* *}(0.000)$ & $4.335^{* * *}(0.000)$ \\
$\boldsymbol{\beta}_{\mathrm{EI}}$ & $3.978^{* *}(0.000)$ & $27.400^{* * *}(0.000)$ \\
$\boldsymbol{\beta}_{\mathrm{ERT}}$ & $4.434^{* * *}(0.000)$ & $0.215(0.951)$ \\
$\boldsymbol{\beta}_{\mathrm{REN}}$ & $13.177^{* * *}(0.000)$ & $6.756^{* * *}(0.000)$ \\
$\boldsymbol{\phi}_{\mathbf{1}}$ & $2.002^{* *}(0.021)$ & $3.017^{* * *}(0.000)$ \\
$\boldsymbol{\omega}_{\mathbf{0}}$ & $0.141(0.999)$ & $1.371(0.197)$ \\
$\boldsymbol{\lambda}_{\mathbf{0}}$ & $2.547^{* *}(0.012)$ & $2.784^{* * *}(0.007)$ \\
$\boldsymbol{\theta}_{\mathbf{0}}$ & $7.101^{* * *}(0.000)$ & $0.841(0.531)$ \\
$\boldsymbol{\varepsilon}_{\mathbf{0}}$ & $0.107(0.999)$ & $0.978(0.451)$ \\
$\boldsymbol{\delta}_{\mathbf{0}}$ & $3.204^{* * *}(0.000)$ & $4.859^{* * *}(0.000)$ \\
\hline
\end{tabular}

Note: CE means $\mathrm{CO}_{2}$ emissions, PM2.5 means particulate matters 2.5, GG stands for green growth, EI means ecological innovation, ERT means environmental taxes, REN means renewable energy. $* * *, * *$, and * reflects significance level at $1 \%, 5 \%$, and $10 \%$, accordingly.

Source: Authors' estimations.

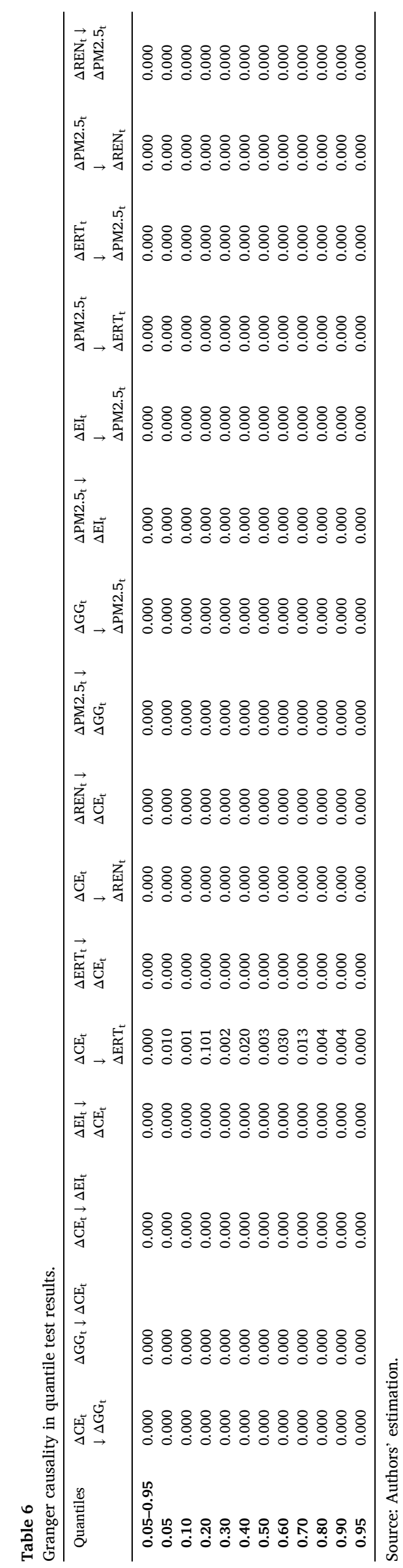


the environmental conditions.

The study outcomes indicated that error correction parameters for the study quantile were significant and negative, confirming the significant revision to the long-term connection among the explanatory and outcome variables. Thus, it is concluded that the USA has successfully maintained their green growth and has successful measures for environmental issues, which are the reason for the negative association among the predictors and $\mathrm{CO}_{2}$ emission. Additionally, the QARDL model for $\mathrm{CO}_{2}$ emission under the long-run estimation confirmed that green growth, the square of green growth, environmental taxes, and renewable energy were observed as significant and negative determinants in lowering such emissions in the USA's natural environment. For the short-run estimation, we observed that the past and lagged values of $\mathrm{CO}_{2}$ emissions, green growth, ecological innovation, and renewable energy were negatively and significantly linked with the current and lagged values of $\mathrm{CO}_{2}$ emissions in the USA. In addition, the impact from green growth, square of green growth, and renewable energy was also found to be negatively significant under the long-run estimation through the QARDL model for PM2.5 for most of the study quantiles. Meanwhile, the short-run estimation showed that the past and lagged values of PM2.5, green growth, ecological innovation, and renewable energy were negatively and significantly linked with the current and lagged values of PM2.5 in different quantiles.

Based on the study findings, various policy implications can be observed specifically in the future sustainable environment, specifically in the USA. As the environmental quality is low in terms of higher $\mathrm{CO}_{2}$ emission and PM2.5 pollution, it is highly suggested that more emphasis is placed on promoting green growth, environmental taxes, ecological and environmentally friendly innovation, and renewable energy sources. This study also recommends that policymakers develop policies related to environmental improvement and effectively implement these policies in the country and force the relevant authorities to take necessary measures. This study also facilitates the regulators with formulating regulations and implementation of these regulations in the country. The study helped change the policymakers' focus towards environmental issues and green growth involvement that improve the country's environmental condition. Consequently, this would show positive and sustainable outcomes both in the current and future time. Additionally, a higher level of penetration from renewable energy sources in the economy of the USA can provide better results compared to some nonrenewable energy sources. For this reason, one straightforward solution can be the replacement of fossil fuel-based energy with renewable energy sources.

\section{Credit author statement}

Fengsheng Chien: Conceptualization, Methodology, Project administration, Writing - original draft. Mohammed Ananzeh: Conceptualization, Writing - review \& editing. Farhan Mirza: Software, Formal analysis, Writing - review \& editing. Abou Bakar: Data curation, Visualization, Supervision, Writing - review \& editing. Hieu Minh Vu: Validation, Investigation, Writing - review \& editing. Quang-Thanh Ngo: Conceptualization, Methodology, Project administration, Writing - review \& editing.

\section{Declaration of competing interest}

The authors declare that they have no known competing financial interests or personal relationships that could have appeared to influence the work reported in this paper.

\section{Acknowledgement}

This research is partly funded by University of Economics Ho Chi Minh City, Vietnam.

\section{References}

Ahmed, F.E., Hashaikeh, R., Hilal, N., 2019. Solar powered desalination-Technology, energy and future outlook. Desalination 453, 54-76.

Al-mulali, U., Lee, J.Y., Mohammed, A.H., Sheau-Ting, L., 2013. Examining the link between energy consumption, carbon dioxide emission, and economic growth in Latin America and the Caribbean. Renew. Sustain. Energy Rev. 26, 42-48.

Aman, M.M., Solangi, K.H., Hossain, M.S., Badarudin, A., Jasmon, G.B., Mokhlis, H., Bakar, A.H.A., Kazi, S.N., 2015. A review of Safety, Health and Environmental (SHE) issues of solar energy system. Renew. Sustain. Energy Rev. 41, 1190-1204.

Anh Tu, C., Chien, F., Hussein, M.A., Ramli Mm, Y., Psi Mm, M.S.S., Iqbal, S., Bilal, A.R., 2021. Estimating role of green financing on energy security, economic and environmental integration of BRI member countries. Singapore Econ. Rev.

APM, 2012. APM body of knowledge definitions. Assoc. Proj. Manag.

Aziz, N., Sharif, A., Raza, A., Rong, K., 2020. Revisiting the role of forestry, agriculture, and renewable energy in testing environment Kuznets curve in Pakistan: evidence from Quantile ARDL approach. Environ. Sci. Pollut. Res. 27, 10115-10128.

Baloch, Z.A., Tan, Q., Kamran, H.W., Nawaz, M.A., Albashar, G., Hameed, J., 2021. A multi-perspective assessment approach of renewable energy production: policy perspective analysis. Environ. Dev. Sustain. 1-29.

Bibi, A., Zhang, X., Umar, M., 2021. The imperativeness of biomass energy consumption to the environmental sustainability of the United States revisited. Environ. Ecol. Stat. https://doi.org/10.1007/s10651-021-00500-9.

Brookes, G., 2019. Glyphosate use in Asia and implications of possible restrictions on its use. AgBioforum 22, 1-26.

Chien, Fengsheng, Ajaz, T., Andlib, Z., Chau, K.Y., Ahmad, P., Sharif, A., 2021a. The role of technology innovation, renewable energy and globalization in reducing environmental degradation in Pakistan: a step towards sustainable environment. Renew. Energy.

Chien, Fengsheng, Chau, K.Y., Ady, S.U., Zhang, Y., Tran, Q.H., Aldeehani, T.M., 2021b. Does the combining effects of energy and consideration of financial development lead to environmental burden: social perspective of energy finance? Environ. Sci. Pollut. Res. 1-14.

Chien, FengSheng, Kamran, H.W., Albashar, G., Iqbal, W., 2021. Dynamic planning, conversion, and management strategy of different renewable energy sources: a sustainable solution for severe energy crises in emerging economies. Int. J. Hydrogen Energy 46, 7745-7758.

Chien, Fengsheng, Ngo, Q.-T., Hsu, C.-C., Chau, K.Y., Iram, R., 2021c. Assessing the mechanism of barriers towards green finance and public spending in small and medium enterprises from developed countries. Environ. Sci. Pollut. Res. 1-16.

Chien, Fengsheng, Pantamee, A.A., Hussain, M.S., Chupradit, S., Nawaz, M.A., Mohsin, M., 2021d. Nexus between financial innovation and bankruptcy: evidence from information, communication and technology (ict) sector. Singapore Econ. Rev. $1-22$.

Chou, J.-S., Yeh, K.-C., 2015. Life cycle carbon dioxide emissions simulation and environmental cost analysis for building construction. J. Clean. Prod. 101, 137-147.

Colander, D.C., Su, H., 2018. How Economics Should Be Done: Essays on the Art and Craft of Economics. Edward Elgar Publishing.

De la Croix, D., Licandro, O., 2015. The longevity of famous people from Hammurabi to Einstein. J. Econ. Growth 20, 263-303.

Diesing, P., Diesing, P., 2019. Neoclassical economics. In: Science \& Ideology in the Policy Sciences. https://doi.org/10.4324/9781315128986-3.

Ding, Q., Khattak, S.I., Ahmad, M., 2021. Towards sustainable production and consumption: assessing the impact of energy productivity and eco-innovation on consumption-based carbon dioxide emissions (CCO2) in G-7 nations. Sustain. Prod. Consum. 27, 254-268.

Ehsanullah, S., Tran, Q.H., Sadiq, M., Bashir, S., Mohsin, M., Iram, R., 2021. How energy insecurity leads to energy poverty? Do environmental consideration and climate change concerns matters. Environ. Sci. Pollut. Res. 1-12.

Godil, D.I., Sharif, A., Agha, H., Jermsittiparsert, K., 2020. The dynamic nonlinear influence of ICT, financial development, and institutional quality on CO2 emission in Pakistan: new insights from QARDL approach. Environ. Sci. Pollut. Res. 27 (19), 24190-24200.

Hao, L.-N., Umar, M., Khan, Z., Ali, W., 2021. Green growth and low carbon emission in G7 countries: how critical the network of environmental taxes, renewable energy and human capital is? Sci. Total Environ. 752, 141853.

Hashmi, R., Alam, K., 2019. Dynamic relationship among environmental regulation, innovation, CO2 emissions, population, and economic growth in OECD countries: a panel investigation. J. Clean. Prod. 231, 1100-1109.

He, X., Adebayo, T.S., Kirikkaleli, D., Umar, M., 2021. Consumption-based carbon emissions in Mexico: an analysis using the dual adjustment approach. Sustain. Prod. Consum. 27, 947-957. https://doi.org/10.1016/j.spc.2021.02.020.

Hsu, C.-C., Quang-Thanh, N., Chien, F., Li, L., Mohsin, M., 2021. Evaluating green innovation and performance of financial development: mediating concerns of environmental regulation. Environ. Sci. Pollut. Res. 1-12.

Huang, S.-Z., Chau, K.Y., Chien, F., Shen, H., 2020. The impact of startups' dual learning on their green innovation capability: the effects of business executives' environmental awareness and environmental regulations. Sustainability 12, 6526.

Ji, X., Zhang, Y., Mirza, N., Umar, M., Rizvi, S.K.A., 2021. The impact of carbon neutrality on the investment performance: evidence from the equity mutual funds in BRICS. J. Environ. Manag. 297, 113228. https://doi.org/10.1016/j. jenvman.2021.113228.

Kahia, M., Jebli, M.B., Belloumi, M., 2019. Analysis of the impact of renewable energy consumption and economic growth on carbon dioxide emissions in 12 MENA countries. Clean Technol. Environ. Policy 21, 871-885. 
Lee, C.T., Hashim, H., Ho, C.S., Fan, Y. Van, Klemeš, J.J., 2017a. Sustaining the lowcarbon emission development in Asia and beyond: sustainable energy, water, transportation and low-carbon emission technology. J. Clean. Prod. https://doi.org/ 10.1016/j.jclepro.2016.11.144.

Lee, C.T., Hashim, H., Ho, C.S., Van Fan, Y., Klemeš, J.J., 2017b. Sustaining the lowcarbon emission development in Asia and beyond: sustainable energy, water, transportation and low-carbon emission technology. J. Clean. Prod. 146, 1-13.

Li, C., Liu, J., Zheng, S., Chen, X., Li, J., Zeng, Z., 2019. Performance analysis of an improved power generation system utilizing the cold energy of LNG and solar energy. Appl. Therm. Eng. 159, 113937.

Li, W., Chien, F., Hsu, C.-C., Zhang, Y., Nawaz, M.A., Iqbal, S., Mohsin, M., 2021a. Nexus between energy poverty and energy efficiency: estimating the long-run dynamics. Resour. Pol. 72, 102063.

Li, W., Chien, F., Kamran, H.W., Aldeehani, T.M., Sadiq, M., Nguyen, V.C., TaghizadehHesary, F., 2021b. The nexus between COVID-19 fear and stock market volatility. Econ. Res.-Ekon. Istraživanja 1-22.

Li, W., Chien, F., Ngo, Q.-T., Nguyen, T.-D., Iqbal, S., Bilal, A.R., 2021c. Vertical financial disparity, energy prices and emission reduction: empirical insights from Pakistan. J. Environ. Manag. 294, 112946.

Li, X.-K., Ji, W.-J., Zhao, J., Wang, S.-J., Au, C.-T., 2005. Ammonia decomposition over $\mathrm{Ru}$ and Ni catalysts supported on fumed SiO2, MCM-41, and SBA-15. J. Catal. 236, $181-189$.

Liu, X., Zhang, S., Bae, J., 2017. The impact of renewable energy and agriculture on carbon dioxide emissions: investigating the environmental Kuznets curve in four selected ASEAN countries. J. Clean. Prod. 164, 1239-1247.

Malla, S., Brewin, D.G., 2020. An economic account of innovation policy in Canada: a comparison of canola, wheat, and pulses. AgBioforum 22, 25-36.

Milonakis, D., 2012. Neoclassical economics. In: The Elgar Companion to Marxist Economics. Edward Elgar Publishing.

Mohsin, M., Kamran, H.W., Nawaz, M.A., Hussain, M.S., Dahri, A.S., 2021. Assessing the impact of transition from nonrenewable to renewable energy consumption on economic growth-environmental nexus from developing Asian economies. J. Environ. Manag. 284, 111999.

Morley, Bruce, 2012. Empirical evidence on the effectiveness of environmental taxes. Appl. Econ. Lett. 19 (18), 1817-1820.

Mundaca, L., Markandya, A., 2016. Assessing regional progress towards a 'green energy economy. Appl. Energy 179, 1372-1394.

Nawaz, M.A., Hussain, M.S., Kamran, H.W., Ehsanullah, S., Maheen, R., Shair, F., 2021a. Trilemma association of energy consumption, carbon emission, and economic growth of BRICS and OECD regions: quantile regression estimation. Environ. Sci. Pollut. Res. 28, 16014-16028.

Nawaz, M.A., Seshadri, U., Kumar, P., Aqdas, R., Patwary, A.K., Riaz, M., 2021b. Nexus between green finance and climate change mitigation in N-11 and BRICS countries: empirical estimation through difference in differences (DID) approach. Environ. Sci. Pollut. Res. 28, 6504-6519.

Nguyen, C.-H., Ngo, Q.-T., Pham, M.-D., Nguyen, A.-T., Huynh, N.-C., 2021. Economic linkages, technology transfers, and firm heterogeneity: the case of manufacturing firms in the Southern Key Economic Zone of Vietnam. Cuad. Econ. 44, 1-25.

Nguyen, T., Yu, X., Zhang, Z., Liu, M., Liu, X., 2015. Relationship between types of urban forest and PM2. 5 capture at three growth stages of leaves. J. Environ. Sci. 27, 33-41.

Othman, Z., Nordin, M.F.F., Sadiq, M., 2020. GST fraud prevention to ensure business sustainability: a Malaysian case study. J. Asian Bus. Econ. Stud.

Pirgmaier, E., 2017. The neoclassical Trojan horse of steady-state economics. Ecol. Econ. 133, 52-61.

Sadiq, M., Singh, J., Raza, M., Mohamad, S., 2020. The impact of environmental, social and governance index on firm value: evidence from Malaysia. Int. J. Energy Econ. Pol. 10, 555.

Schmidt, T.S., Huenteler, J., 2016. Anticipating industry localization effects of clean technology deployment policies in developing countries. Global Environ. Change 38, $8-20$.

Shahbaz, M., Lahiani, A., Abosedra, S., Hammoudeh, S., 2018. The role of globalization in energy consumption: a quantile cointegrating regression approach. Energy Econ. 71, 161-170.

Shair, F., Shaorong, S., Kamran, H.W., Hussain, M.S., Nawaz, M.A., 2021a. Assessing the efficiency and total factor productivity growth of the banking industry: do environmental concerns matters? Environ. Sci. Pollut. Res. 28, 20822-20838.

Shair, F., Shaorong, S., Kamran, H.W., Hussain, M.S., Nawaz, M.A., 2021b. Assessing the efficiency and total factor productivity growth of the banking industry: do environmental concerns matters? Environ. Sci. Pollut. Res. 28, 20822-20838.
Sharif, A., Afshan, S., Chrea, S., Amel, A., Khan, S.A.R., 2020. The role of tourism, transportation and globalization in testing environmental Kuznets curve in Malaysia: new insights from quantile ARDL approach. Environ. Sci. Pollut. Res. 27 (20), 25494-25509.

Sharif, A., Baris-Tuzemen, O., Uzuner, G., Ozturk, I., Sinha, A., 2020. Revisiting the role of renewable and non-renewable energy consumption on Turkey's ecological footprint: evidence from Quantile ARDL approach. Sustain. Cities Soc. 57, 102138.

Su, C.-W., Sun, T., Ahmad, S., Mirza, N., 2021a. Does institutional quality and remittances inflow crowd-in private investment to avoid Dutch Disease? A case for emerging seven (E7) economies. Resour. Pol. 72, 102111. https://doi.org/10.1016/ j.resourpol.2021.102111.

Su, Z.-W., Umar, M., Kirikkaleli, D., Adebayo, T.S., 2021. Role of political risk to achieve carbon neutrality: Evidence from Brazil. J. Environ. Manag. 298, 113463. https:// doi.org/10.1016/j.jenvman.2021.113463.

Su, C.-W., Yuan, X., Tao, R., Umar, M., 2021b. Can new energy vehicles help to achieve carbon neutrality targets? J. Environ. Manag. 297, 113348. https://doi.org/ 10.1016/j.jenvman.2021.113348.

Suki, N.M., Sharif, A., Afshan, S., Suki, N.M., 2020. Revisiting the Environmental Kuznets Curve in Malaysia: The role of globalization in sustainable environment. J. Clean. Prod. 264, 121669.

Sun, H., Awan, R.U., Nawaz, M.A., Mohsin, M., Rasheed, A.K., Iqbal, N., 2020. Assessing the socio-economic viability of solar commercialization and electrification in south Asian countries. Environ. Dev. Sustain. 1-23.

Tao, R., Umar, M., Naseer, A., Razi, U., 2021. The dynamic effect of eco-innovation and environmental taxes on carbon neutrality target in emerging seven (E7) economies. J. Environ. Manag. 299, 113525. https://doi.org/10.1016/j.jenvman.2021.113525.

Triki-Lahiani, A., Abdelghani, A.B.-B., Slama-Belkhodja, I., 2018. Fault detection and monitoring systems for photovoltaic installations: a review. Renew. Sustain. Energy Rev. 82, 2680-2692.

Umar, M., Ji, X., Kirikkaleli, D., Alola, A.A., 2021a. The imperativeness of environmental quality in the United States transportation sector amidst biomass-fossil energy consumption and growth. J. Clean. Prod. 285, 124863. https://doi.org/10.1016/j jclepro.2020.124863.

Umar, M., Ji, X., Kirikkaleli, D., Shahbaz, M., Zhou, X., 2020a. Environmental cost of natural resources utilization and economic growth: can China shift some burden through globalization for sustainable development? Sustain. Dev. 28, 1678-1688. https://doi.org/10.1002/sd.2116.

Umar, M., Ji, X., Kirikkaleli, D., Xu, Q., 2020b. COP21 Roadmap: do innovation, financial development, and transportation infrastructure matter for environmental sustainability in China? J. Environ. Manag. 271, 111026. https://doi.org/10.1016/j. jenvman.2020.111026.

Umar, M., Ji, X., Mirza, N., Naqvi, B., 2021b. Carbon neutrality, bank lending, and credit risk: evidence from the Eurozone. J. Environ. Manag. 296, 113156. https://doi.org/ 10.1016/j.jenvman.2021.113156.

Umar, M., Su, C.-W., Rizvi, S.K.A., Lobonţ, O.-R., 2021. Driven by fundamentals or exploded by emotions: Detecting bubbles in oil prices. Energy 231, 120873. https:// doi.org/10.1016/j.energy.2021.120873.

Wang, K.-H., Su, C.-W., Lobonţ, O.-R., Umar, M., 2021a. Whether crude oil dependence and $\mathrm{CO} 2$ emissions influence military expenditure in net oil importing countries? Energy Pol. 153, 112281. https://doi.org/10.1016/j.enpol.2021.112281.

Wang, K.-H., Su, C.-W., Umar, M., 2021b. Geopolitical risk and crude oil security: a Chinese perspective. Energy 219, 119555. https://doi.org/10.1016/j. energy.2020.119555.

Wang, J., Umar, M., Afshan, S., Haouas, I., 2021. Examining the nexus between oil price, COVID-19, uncertainty index, and stock price of electronic sports: fresh insights from the nonlinear approach. Economic Research-Ekonomska Istraživanja 0, 1-17. https://doi.org/10.1080/1331677X.2021.1937260.

Wang, K.-H., Umar, M., Akram, R., Caglar, E., 2021c. Is technological innovation making world "Greener"? An evidence from changing growth story of China. Technol. Forecast. Soc. Change 165, 120516. https://doi.org/10.1016/j. techfore.2020.120516.

Yao, S., Zhang, S., Zhang, X., 2019. Renewable energy, carbon emission and economic growth: a revised environmental Kuznets Curve perspective. J. Clean. Prod. 235, 1338-1352.

Zhang, J., Dai, Y., Su, C.-W., Kirikkaleli, D., Umar, M., 2021. Intertemporal change in the effect of economic growth on carbon emission in China. Energy Environ. https://doi. org/10.1177/0958305X211008618.

Zhuang, Y., Yang, S., Chupradit, S., Nawaz, M.A., Xiong, R., Koksal, C., 2021. A nexus between macroeconomic dynamics and trade openness: moderating role of institutional quality. Bus. Process Manag. J. 